\title{
PEMBUATAN VIRGIN COCONUT OIL (VCO) DENGAN MENGGUNAKAN CARA TRADISIONAL
}

\author{
Chalis Fajri Hasibuan ${ }^{1)}$, Rahmiati' ${ }^{2)}$, Jamilah Nasution ${ }^{2)}$ \\ ${ }^{1)}$ Fakultas Teknik Unversitas Medan Area \\ ${ }^{2)}$ Fakultas Biologi Unversitas Medan Area \\ chalisfajri@yahoo.co.id
}

DOI : 10.31604/j.martabe.v1i3.128-132

\begin{abstract}
Virgin coconut oil is the oil obtained from the extraction is performed from a fresh coconut fruit is processed in various ways, one of which is to use the traditional way using the maximum scale for the production of equipment home-based, the purpose of the manufacture of virgin coconut oil is to give users information results in the form of coconut milk can be processed back into the VCO oil has a high value and usefulness as medicine has, of the results. Making VCO is done by way of practice together between presenters with partners. It was first performed by the presenters next demonstration followed by a partner who is guided by the presenters. The procedure of making VCO consists of: the preparation of raw material, Cleavage, grind coconut, grated coconut, and coconut milk into extortion, heat coconut milk until it becomes a VCO with maximum temperature $70^{\circ} \mathrm{C}$.
\end{abstract}

Key words: Virgin Coconut Oil, Production Process, Biological Industry.

\begin{abstract}
Abstrak
Virgin coconut oil merupakan minyak yang diperoleh dari ekstraksi yang dilakukan dari buah kelapa segar yang diproses dengan berbagai cara salah satunya adalah dengan menggunakan cara tradisional dengan menggunakan peralatan maksimal untuk produksi skala rumahan, tujuan dari pembuatan virgin coconut oil ini adalah untuk memberikan informasi pemanfaat hasil kelapa yang berupa santan yang dapat diolah kembali menjadi minyak VCO yang memiliki nilai jual yang tinggi dan memiliki kegunaan sebagai obat, dari hasil. Cara pembuatan VCO dilakukan dengan cara praktek bersamasama antara pemateri dengan mitra. Pertama kali dilakukan demonstrasi oleh pemateri yang selanjutnya diikuti oleh mitra yang dipandu oleh pemateri. Prosedur pembuatan VCO terdiri dari: persiapan bahan baku, Pembelahan Kelapa, pemarutan kelapa, pemerasan kelapa parut menjadi santan, pemanasaan santan sampai menjadi VCO dengan suhu maksimal $70^{\circ} \mathrm{C}$.
\end{abstract}

Kata kunci: Virgin Coconut Oil, Proses Produksi, Biologi Industri. 


\section{PENDAHULUAN}

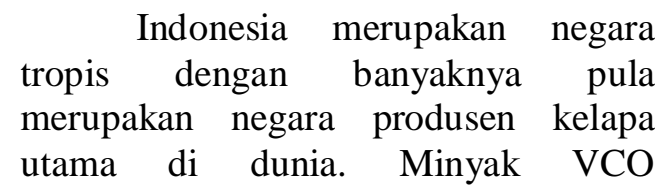
merupakan minyak yang diperoleh dari kopra (daging buah kelapa yang dikeringkan) atau dari perasan santannya. Kandungan minyak pada daging buah kelapa tua diperkirakan mencapai $30 \%-35 \%$, atau kandungan minyak dalam kopra mencapai $63-72 \%$. Kebutuhan akan Minyak VCO terpenuhi dengan adanya pemanfaatan lahan tanaman kelapa sekitar 3,712 juta hektar. Kebutuhan Minyak VCO dari waktu ke waktu semakin meningkat seiring dengan semakin mahalnya minyak jenis lain. Berbagai cara telah dilakukan untuk memperoleh hasil olahan minyak VCO, mulai dari cara tradisional sampai dengan cara modern.

Produk kelapa yang paling berharga adalah Minyak VCO. Minyak VCO dapat diperoleh dari daging buah kelapa segar atau dari kopra. Proses untuk membuat Minyak VCO dari daging buah kelapa segar dikenal dengan proses basah (wet process), karena pada proses ini ditambahkan air untuk mengekstraksi minyak. Sedangkan pembuatan Minyak VCO dengan bahan baku kopra dikenal dengan proses kering (dry process) (Susanto, 2013).

Minyak VCO murni banyak digunakan dalam industri farmasi, kosmetika, susu formula, maupun sebagai minyak goreng mutu tinggi. Minyak VCO murni dapat menanggulangi beragam penyakit pada manusia. Untuk pengobatan penyakit, Minyak VCO murni digunakan untuk mengobati HIV-AIDS, kanker, hepatitis, osteoporosis, diabetes, penyakit jantung, obesitas, dan berbagai penyakit yang disebabkan oleh mikroba (Ahmad, 2006).

Untuk kosmetika, Minyak VCO murni sering digunakan pada minyak telon, handbody, atau pelembap wajah. Selain itu, Minyak VCO murni juga mampu memperbaiki sistem pencernaan. Hal ini dikarenakan asam lemak rantai menengah (MCFA) yang terkandung dalam VCO langsung dapat diserap melalui dinding usus tanpa harus mengalami proses hidrolisis dan enzimatis sehingga langsung dimetabolisme dalam hati untuk diproduksi menjadi energi. VCO juga dapat digunakan untuk memasak dan menggoreng. Minyak VCO direkomendasikan dengan kuat oleh para dokter di Amerika sebagai ingredien dalam susu formula dan sapihan, (Rindengan, 2007).

Mitra dalam Pengabdian pada masayarakt ini adalah siswa SMA dan mahasiswa dari Universitas Medan Area Fakultas Teknik dan Biologi. Pelaksanaan pengabdian ini dilakukan untuk memberikan pemahaman kepada siswa dan mahasiswa tentang penerapan proses produksi berkelanjutan dari tanaman yang banyak digunakan oleh masyarakat yang memiliki nilai ekonomis yang tinggi, pelatihan ini dilakukan dengan cara tradisional yang bertujuan agar setelah diberikan pelatihan mahasiswa dan sisiwa dapat mengaplikasikan dengan baik dan mudah sehingga dapat menumbuhkan jiwa entrepreneur di kalangan mahasiswa dan siswa SMA Teladan Medan.

Adapun yang menjadi tujuan dalam kegiatan pengabdian ini yaitu mengetahui, memahami proses pengolahan, pengujian hasil, dan menganalisis biaya-biaya yang terjadi dalam proses pembuatan minyak VCO dengan metode tradisional. 


\section{METODE PELAKSANAAN}

Kegiatan pengabdian kepada masyarakat berlangsung selama 2 hari yaitu pada hari Jumat dan Sabtu (20 21 April 2018 ) pukul $10.00-15.00$ WIB. Kegiatan pada hari ke-1 dilaksanakan di laboratorium IPA SMA Teladan Medan. Sedangkan kegiatan pada hari ke-2 dilaksanakan di laboratorium Proses Manufaktur Univeritas Medan Area. Kegitan yang dilakukan berupa penyampaian materi dan praktek langsung pembuatan Minyak VCO. Peserta dibagi dalam 4 kelompok.

Setiap kelompok melakukan praktek langsung setelah diberikan penjelasan oleh tim pelaksana kegiatan. Metode pelaksanaan kegiatan yaitu dengan cara persentasi dan pelatihan pembuatan VCO secara langsung.

\section{HASIL DAN PEMBAHASAN}

\section{Hari ke-1}

a. Pemaparan materi tentang perkembangan industri VCO dan pemaparan cara-cara produksi Minyak VCO yang sudah ada baik skala rumahan atau skala industry.

b. Pemaparan tentang desain kemasan VCO.

c. Diskusi antara pelaksana kegiatan dengan mitra (Mahasiswa dan siswa SMA Teladan).

\section{Hari ke-2}

a. Pelatihan pembuatan VCO dengan cara Tradisional.

Metode pembuatan VCO terdiri dari: persiapan alat dan bahan, Pembelahan kelapa, pemarutan kelapa, pemerasan kelapa menjadi santan kelapa, pemanasan kelapa hingga menjadi minyak dan pengemasan minyak VCO.

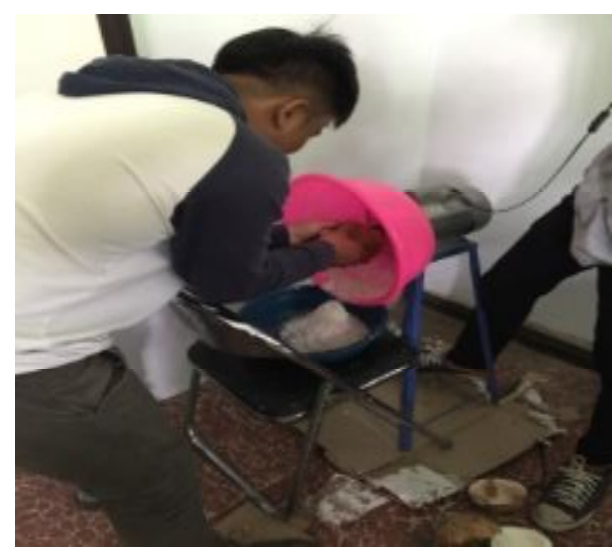

Gambar 1: Pemarutan Kelapa

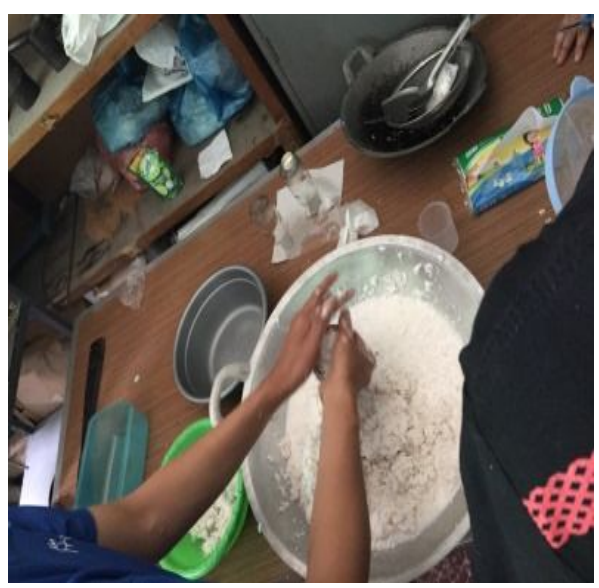

Gambar 2: Pemerasan Kelapa

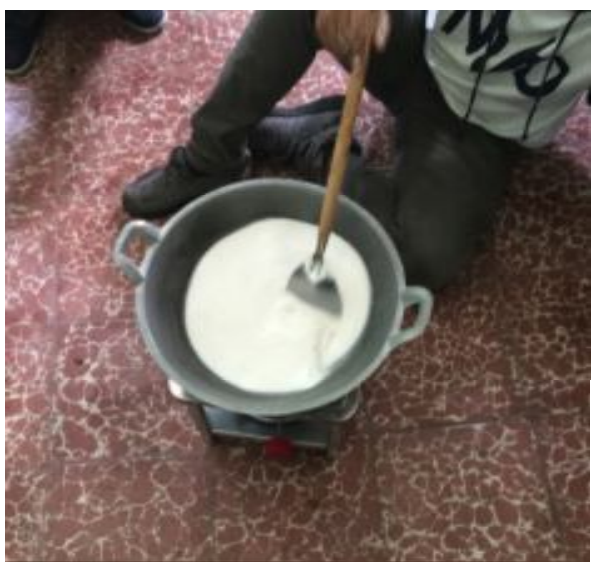

Gambar 3: Pemanasan Kelapa 


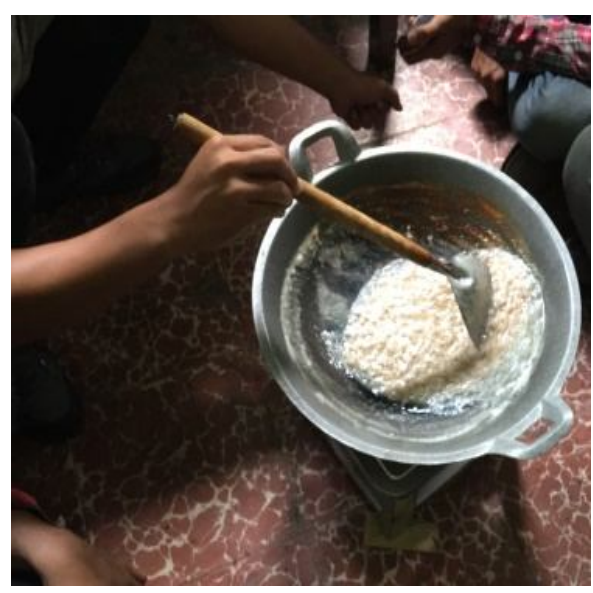

Gambar 4: Minyak VCO Terbentuk

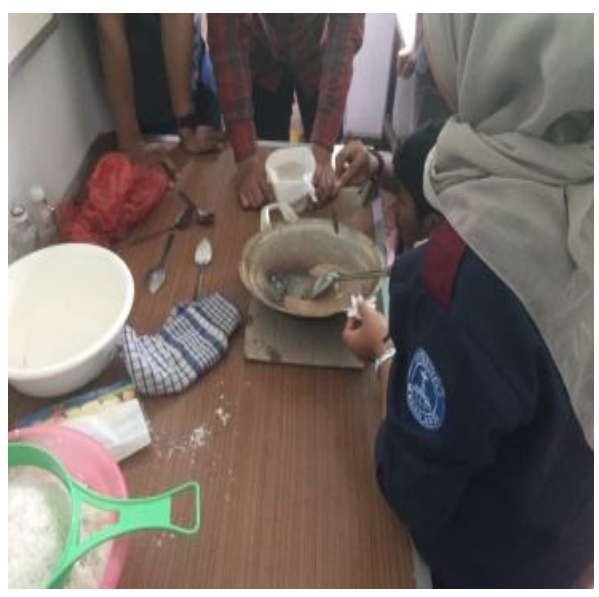

Gambar 5: Penyaringan Minyak VCO

b. Pengujian Kualitas VCO

Pengujian kulitas VCO dilakukan dengan cara menilai bilangan penyabunan dan biangan asam dari VCO.

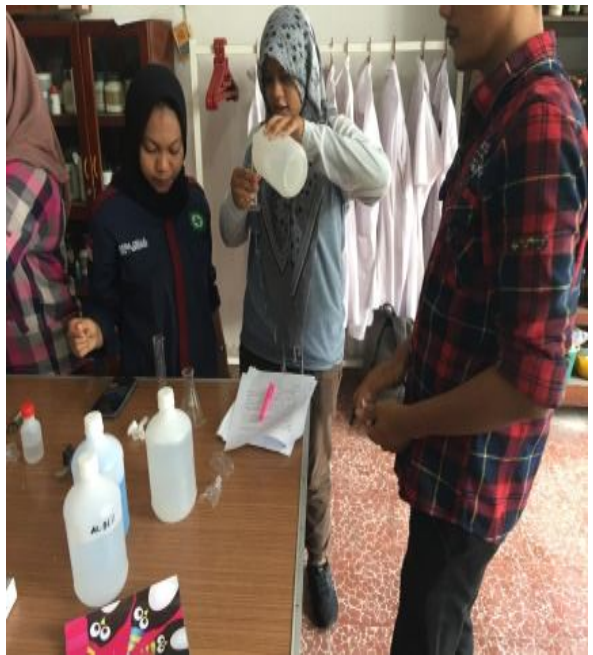

Gambar 5: Pengujian kulitas VCO

\section{Perhitungan Biaya Produksi Metode Tradisional}

Produksi minyak kelapa metode tradisional dalam satu hari dilakukan sebanyak tiga kali produksi. Sekali produksi membutuhkan waktu sebanyak 2 jam. Dalam setiap bulannya pekerja bekerja selama 24 hari kerja.

Biaya produksi dalam proses pembuatan minyak kelapa dengan metode tradisional dapat dilihat pada tabel 1 .

Tabel 1: Perhitungan Biaya Bahan Pembuatan Minyak VCO Metode Tradisional

\begin{tabular}{|c|c|c|c|c|c|}
\hline No. & Biaya & Bahan & Jumlah & @ (Rp) & $\begin{array}{c}\text { Total / } \\
\text { Produksi (Rp) }\end{array}$ \\
\hline 1 & \multirow{3}{*}{$\begin{array}{l}\text { Bahan baku } \\
\text { Bahan } \\
\text { tambahan } \\
\text { Bahan } \\
\text { penolong }\end{array}$} & Kelapa & 3 buah & 5000/buah & 15.000 \\
\hline 2 & & $\begin{array}{l}\text { Botol kemasan } \\
600 \mathrm{ml}\end{array}$ & 1 buah & 2500/buah & 2.500 \\
\hline 3 & & Minyak tanah & $\begin{array}{l}0,95 \\
\text { liter }\end{array}$ & $9.000 / \mathrm{L}$ & 8.550 \\
\hline & & Total & & & 18.850 \\
\hline
\end{tabular}


Chalis Fajri Hasibuan, dkk. Pembuatan Virgin Coconut Oil (VCO)...

\section{SIMPULAN}

Dari hasil pelaksanaan kegiatan diperoleh bahwa Meningkatnya pengetahuan dan pemahaman siswa SMA Teladan Medan dan Mahasiswa tentang pembuatan VCO. Meningkatnya pengetahuan dan pemahaman siswa SMA Teladan Medan dan Mahasiswa tentang potensi Kelapa menjadi Minyak VCO. Meningkatnya keterampilan siswa SMA Teladan Medan dan Mahasiswa dalam membuat VCO secara sederhana berbasis biologi industri, sehingga dimungkinkan peserta dapat membuat sendiri VCO di rumah sebagai materi praktikum di sekolah. Mengetahui biaya produksi pembuatan minyak VCO yang cukup murah

\section{DAFTAR PUSTAKA}

Susanto, Tri. 2013. Perbandingan Mutu Minyak Kelapa yang di Proses Melalui Pengasaman dan Pemanasan Sesuai SNI 29022011. Palembang: Jurnal Balai Riset dan Standardisasi Industri Ahmad. 2006. Teknologi Pengolahan Minyak Kelapa. Jakarta: MAPI

Rindengan. 2007. Minyak Kelapa Murni: Pembuatan dan Pemanfaatan. Jakarta: Swadaya 